\title{
A review on traditional uses, phytochemistry, and pharmacology of the genus Rourea
}

\author{
Che Puteh Osman ${ }^{1 *}$, Zuriati Zahari ${ }^{1}$, Mohd Ilham Adenan ${ }^{1}$, Rozaini Mohd Zohdi \\ ${ }^{1}$ Faculty of Applied Sciences, Universiti Teknologi MARA, 40450 Shah Alam, Selangor, Malaysia. \\ ${ }^{2}$ Atta-ur-Rahman Institute for Natural Products Discovery, Universiti Teknologi MARA, Selangor Branch, Puncak Alam Campus, 42300 Bandar Puncak \\ Alam, Selangor, Malaysia.
}

\section{ARTICLE INFO \\ Received on: $23 / 08 / 2018$ \\ Accepted on: 14/02/2019 \\ Available online: 01/09/2019}

\section{Key words:}

Rourea; Connoraceae;

flavonoids; Rourea

minor; Rourea induta;

ethnomedicine

\begin{abstract}
Rourea is a genus of climbing shrubs and small trees and widely distributed in the Amazon, Pacific region, Africa, and Asia. It has about 65 species and 129 varieties. They are widely used in ethnomedicine for various health complaints such as rheumatism, diabetes, tumor, asthma, and diarrhea. This paper summarizes 38 compounds from Rourea sp. from different classes of compounds such as flavonoids, triterpenes, phenolic compounds, lipids, phytosteroids, and coumarin. Several bioactivities such as hypoglycemia, antinociceptive, antibacterial, antioxidant, antiplasmodial, and larvicidal activities are also discussed.
\end{abstract}

\section{INTRODUCTION}

Rourea is a genus in the Connaraceae family. Genus Rourea has about 65 species and 129 varieties (The Plant List, 2013). Rourea is a climbing shrub or small tree, usually with prominent lenticels. The leaflets are small and imparipinnate. An unbranched inflorescence bears flowers of five petals in the calyx. They have longer petals than sepals. The fruits are curved and hairless. Rourea sp. is widely distributed in the Amazon, Pacific region, Africa, and Asia (Forero, 2009). Some of Rourea sp. are poisonous, while others are widely used in traditional medicine. There are several reports on the potential of Rourea sp. as hypoglycemic agents. Despite their wide application in ethnomedicine, very few scientific reports on their chemical constituents and biological activity are documented.

\section{${ }^{*}$ Corresponding Author}

Che Puteh Osman, Faculty of Applied Sciences, Universiti Teknologi

MARA, 40450 Shah Alam, Selangor, Malaysia.

E-mail: cheputeh@salam.uitm.edu.my

\section{TRADITIONAL USES}

In Malaysia, several Rourea species are used by the local communities. The decoction of the roots of $R$. regusa Planch, locally known as akar semeling, is traditionally used to treat respiratory diseases (Alsarhan et al., 2012). The roots decoction of $R$. concolor, locally known as akar semelit in Malaysia, is used by Temuan villagers to treat kidney diseases, diabetes (Ong et al., 2011a), lung tumor, and stomach tumor (Ong et al., 2011b). R. mimosoides or sembelit merah is traditionally used to treat bloody diarrhea, as diuretics (Grosvenor et al., 1995), and to treat bloody cough (Sabran et al., 2016). The roots decoction of R. humilis Blume or akar kayu mengecut is used to improve the contraction of the uterus (Jamal et al., 2011).

$R$. induta Planch is commonly known as chapeudinha, pau-de-porco, or campeira and is widely distributed in Brazil. It is traditionally used in folk medicine to treat rheumatisms and Chagas disease (Kalegari et al., 2014a). R. cuspidate Benth ex. Baker is commonly known in Brazil as miraruira, cip'o miraruira, and muiraruira. It is traditionally used to treat diabetes (Laikowski et al., 2017).

R. coccinea Benth, commonly known as Tomigavi, is used in Togo for the treatment of paralyses and Alzheimer's disease 
(Kantati et al., 2016). R. coccinea is also utilized in Benin traditional medicine for the treatment of male and female infertility, sexual asthenia, blennorrhoea, snakebites, furuncles, and malaria (Bero et al., 2009). The leaves of $R$. minor are used as a styptic to treat minor abrasions and lesions in Chinese folk medicine. The stems and roots of $R$. minor are poisonous; however, they are widely used as tying material (He et al., 2006). R. volubis, $R$. orientalis, $R$. platysepala, and $R$. glabra are poisonous and they are often used to deter animals (Jeannoda et al., 1985; Oliveira et al., 2012). The roots of $R$. santaloides (Vahl.) Wight \& Arnott is traditionally taken for the treatment of joint pains and asthma (Bargali et al.,
2003). R. puberela Baker is used in Chazuta Valley of Peruvian Amazon for its diuretic property (Sanz-Biset \&Canigueral, 2011).

\section{PHYTOCHEMISTRY}

\section{Flavonoids}

Isolation from ethanolic leaves extract of Rourea induta yielded quercetin 1, and three glycosylated derivatives, quercetin-3-O- $\alpha$-arabinofuranoside 2 , quercetin-3-O- $\beta$-xyloside 3, and quercetin-3-O- $\beta$-galactoside 4 (Kalegari et al., 2011). Procyanidin C1 5 was isolated from the aqueous leaves extract<smiles>[R]c1c(-c2ccc(O)c(O)c2)oc2cc(O)cc(O)c2c1=O</smiles>

\begin{tabular}{|l|l|}
\hline & R \\
\hline $\mathbf{1}$ & H \\
\hline $\mathbf{2}$ & - arabinofuranoside \\
\hline $\mathbf{3}$ & -xyloside \\
\hline $\mathbf{4}$ & -galactoside \\
\hline $\mathbf{6}$ & $\beta$-galactopyranosyl \\
\hline $\mathbf{9}$ & -O-rutinoside \\
\hline
\end{tabular}<smiles>Oc1cc(O)c2c(c1)O[C@H](c1ccc(O)c(O)c1)[C@H](O)[C@H]2c1c(O)cc(O)c2c1O[C@H](c1ccc(O)c(O)c1)[C@H](c1c(O)cc(O)c3c1O[C@H](c1ccc(O)c(O)c1)[C@H](O)C3)[C@H]2O</smiles><smiles>[R20]Oc1ccc(-c2oc3cc(O[R20])cc(O)c3c(=O)c2O)cc1</smiles>

\begin{tabular}{|l|l|l|}
\hline & $\mathrm{R}_{1}$ & $\mathrm{R}_{2}$ \\
\hline $\mathbf{7}$ & $\mathrm{CH}_{3}$ & $\mathrm{CH}_{3}$ \\
\hline $\mathbf{8}$ & $\mathrm{H}$ & $\mathrm{H}$ \\
\hline
\end{tabular}<smiles>Oc1ccc([C@@H]2Oc3cc(O)cc(O)c3[C@@H](O)[C@H]2O)cc1</smiles>

10

Figure 1. Flavonoids in Rourea sp. (Kalegari et al., 2011; 2014b; Oliveira et al., 2012; Ramiah et al., 1976; Zhang et al., 2008).

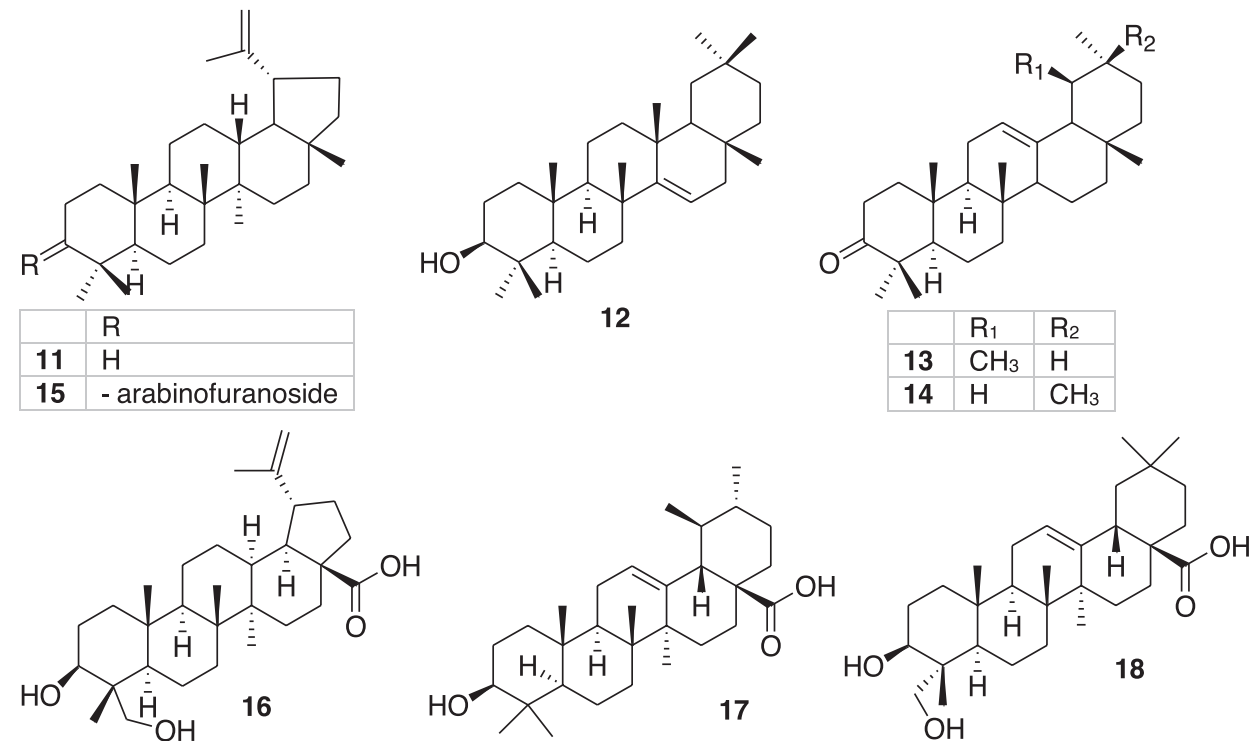

Figure 2. Triterpenes in Rourea sp. (Oliveira et al., 2012; Zhang et al., 2008). 

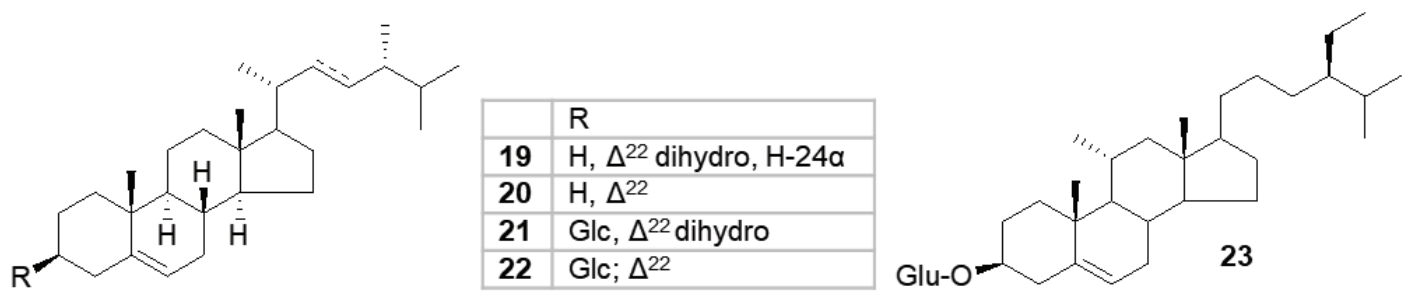

Figure 3. Phytosteroids in Rourea sp. (He et al., 2006; Oliveira et al., 2012).
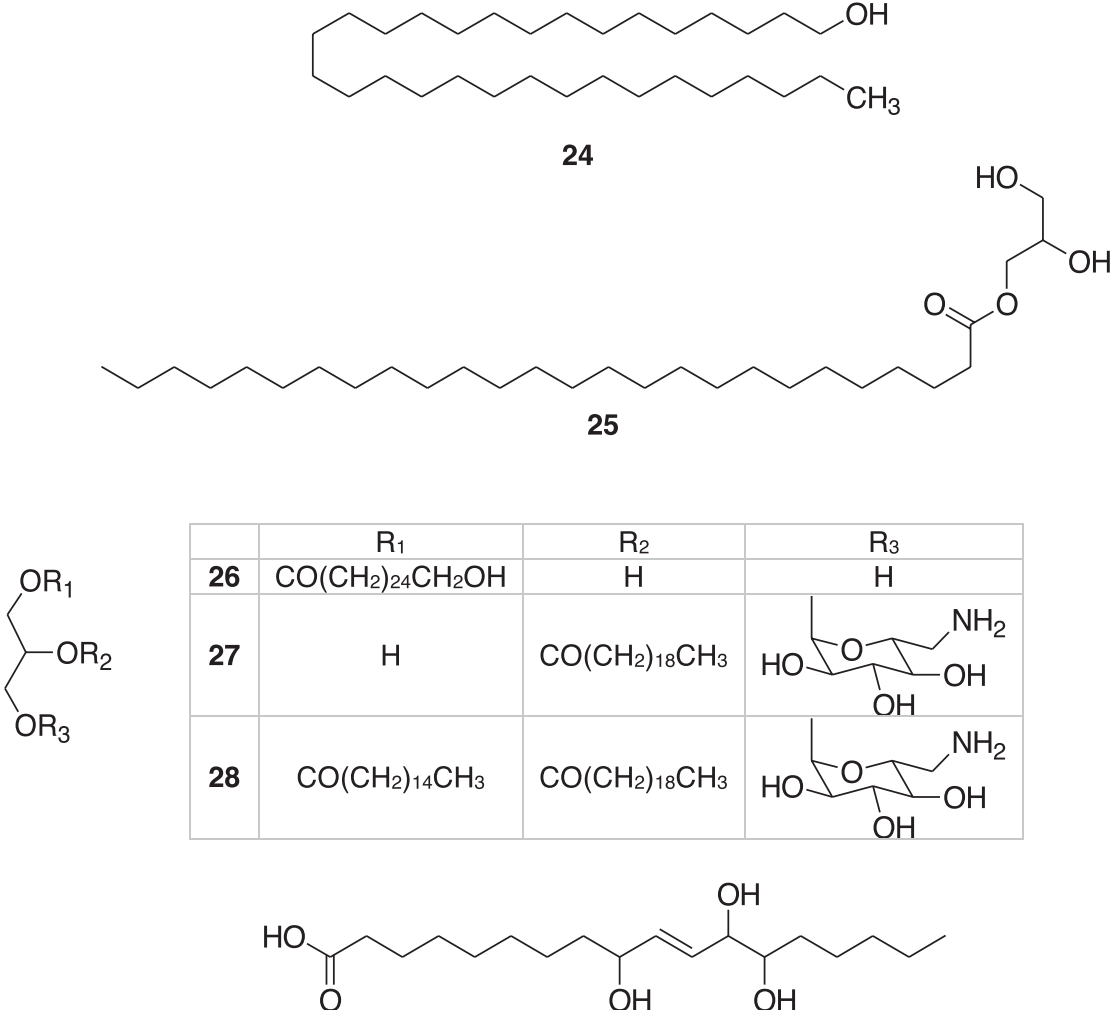

29

Figure 4. Lipids in Rourea sp. (He et al., 2006; Zhang et al., 2008).

of $R$. induta (Kalegari et al., 2014b). HPLC titration of the aqueous leaves extract of $R$. induta revealed the presence of hyperin 6, as well as compounds 2-4 (Kalegari et al., 2014b). The phytochemical study on the chloroform fraction of ethanolic leaves extract of $R$. doniana led to the isolation of 7,4'-dimethylkaempferol 7 (Oliveira et al., 2012). Kaempferol 8 and rutin 9 were reported in $R$. microphylla (Zhang et al., 2008). Leucopelargonidin $\mathbf{1 0}$ was isolated from the roots of $R$. santoloides (Ramiah et al., 1976).

\section{Triterpenes}

Purification of hexane fraction of ethanolic leaves extract of $R$. doniana yielded lupeol 11, lupenone 12, $\alpha$-amyrenone 13, $\beta$-amyrenone 14, and taraxerol 15 (Oliveira et al., 2012). Phytochemical study on $R$. microphylla gave 23-hydroxybetulinic acid 16, ursolic acid 17, and hederagenin 18 (Zhang et al., 2008).

\section{Phytosteroids}

Isolation on chloroform fractions of ethanolic leaves extract of $R$. doniana yielded $\beta$-sitosterol 19, stigmasterol 20 , $\beta$-sitosteryl-3-O- $\beta$-D-glucopyranoside 21, and stigmasteryl-3O- $\beta$-D-glucopyranoside 22 (Oliveira et al., 2012). $\beta$-sitosterol glucoside 23 was isolated from $R$. minor (He et al., 2006).

\section{Lipids}

1-Hentriacontanol 24 and 1-hexacosanoyl glycerol 25 were isolated from $R$. microphylla (Zhang et al., 2008). Isolation on chloroform soluble fraction of methanolic stems extract of $R$. minor gave 1-(26-hydroxyhexacosanoyl)glycerol 26, 1-O-ß-D-glucopyranosyl-(2S,3R,4E-8Z)-2-N-(20hydroxypalmitoyl)-octadecasphinga-4,8-dienine 27 , rourimin 28, and 9S,12S, 13S-trihydroxy-10E-octadecenoic acid 29 (He et al., 2006). 
<smiles>COc1cc2ccc(=O)oc2cc1O</smiles>

30<smiles>O=c1ccc2ccc(O)c(O)c2o1</smiles>

31
Figure 5. Coumarin in Rourea sp. (Oliveira et al., 2012; Zhang et al., 2008).

\section{Coumarin}

Scopeletin 30 was purified from chloroform fraction of ethanolic leaves extract of $R$. doniana (Oliveira et al., 2012). Daphnetin 31 was reported from $R$. microphylla (Zhang et al., 2008).

\section{Phenolic acid}

Purification of the aqueous leaves extract of $R$. induta yielded chlorogenic acid $\mathbf{3 2}$ and neochlorogenic acid $\mathbf{3 3}$ (Kalegari et al., 2014b). (E)-Ferulic acid nonacosyl ester 34 was isolated from $R$. microphylla (Zhang et al., 2008).

\section{Others}

Purification of hexane fraction of ethanolic leaves extract of $R$. induta yielded n- tetracosane 35 (Kalegari et al., 2011). Ropanone 36 was purified from $R$. santoloides (Ramiah et al., 1976). Isolation of chloroform soluble fraction of methanolic stems extract of $R$. minor yielded dihydrovomifoliol-9- $\beta$-D-glucopyranoside $37(\mathrm{He}$ et al., 2006). Rourinoside $\mathbf{3 8}$ was isolated from the chloroform soluble fraction of methanolic stems extract of $R$. minor (He et al., 2006).

\section{BIOLOGICAL ACTIVITY}

\section{Hypoglycemic activity}

\section{Rourea minor}

The methanol roots extract of $R$. minor showed antihyperglycemic activity in a dose-dependent manner at 200 and $400 \mathrm{mg} / \mathrm{kg}$ when administered to streptozotocin-induced diabetic rats. In oral glucose tolerance test, no glucose lowering effect was observed at 30 and 60 minutes but the effect was quite<smiles>O=C(/C=C/c1ccc(O)c(O)c1)OC1C[C@](O)(C(=O)O)C[C@H](O)C1O</smiles><smiles>O=C(/C=C/c1ccc(O)c(O)c1)O[C]1C[C@](O)(C(=O)O)CC(O)[C@H]1O</smiles><smiles>CCCCCCOC(=O)/C=C/c1ccc(O)c(OC)c1</smiles>

Figure 6. Phenolic acids in Rourea sp. (Kalegari et al., 2014b; Zhang et al., 2008).

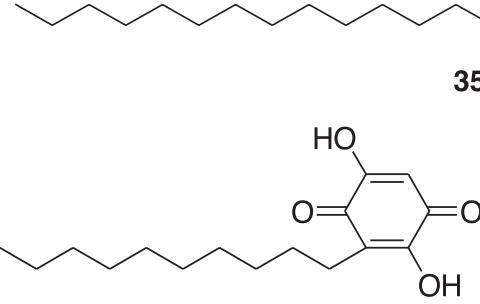

36<smiles>COC(C)C=CC1(O)[C@@H](C)CC(=O)CC1(C)C</smiles>

37<smiles>COc1cc([C@@H](OCl)[C@H](CO)Oc2c(OC)cc(CCCO)cc2OC)ccc1O</smiles> 
Table 1. Bioactivities of Rourea sp.

\begin{tabular}{|c|c|c|c|c|}
\hline Species & Bioactivity & Plant parts & Type of preparation & Main finding \\
\hline \multirow{5}{*}{ R. minor } & \multirow[t]{2}{*}{ Hypoglycemic activity } & Roots & Methanol extract & $\begin{array}{l}\text { The extracts at all doses are effective in lowering glucose level after } 60 \\
\text { minutes in the oral glucose tolerance test. Administration of the extract } \\
\text { resulted in a significant reduction of hyperglycemia in dose- dependent } \\
\text { manner (Chaudhary et al., 2012). }\end{array}$ \\
\hline & & Roots & Ethanol and water extracts & $\begin{array}{l}\text { Treatment with the extracts reduced glycemia significantly and resulted in } \\
\text { higher insulin secretion than the negative control group (Kulkarni et al., } \\
\text { 2014). }\end{array}$ \\
\hline & \multirow{2}{*}{ Acute toxicity } & Roots & Methanol extract & $\begin{array}{l}\text { No acute toxicity was observed when rats were given } 100,200 \text {, and } 400 \\
\mathrm{mg} / \mathrm{kg} \text { of methanolic extract (Chaudhary et al., 2012). }\end{array}$ \\
\hline & & Roots & Ethanol and water extracts & $\begin{array}{l}\text { The rats showed good tolerance up to } 3 \mathrm{~g} / \mathrm{kg} \text { and no lethality was observed } \\
\text { (Kulkarni et al., 2014). }\end{array}$ \\
\hline & Antiplasmodial activity & Dried vines & $\begin{array}{l}\text { Chloroform fraction of } \\
\text { methanol extract. }\end{array}$ & $\begin{array}{l}\text { Compounds } \mathbf{3 8}, \mathbf{2 8} \text {, and } \mathbf{2 6} \text { isolated from } R \text {. minor showed antiplasmodial } \\
\text { activity in vitro against chloroquine sensitive (D6) and chloroquine } \\
\text { resistant (W6) Plasmodium falciparum with the } \mathrm{IC}_{50} \text { values of about } 10 \\
\mu \mathrm{M} \text { (He et al., 2006). }\end{array}$ \\
\hline \multirow{6}{*}{ R. induta } & $\begin{array}{l}\text { Hepatoprotective } \\
\text { activity }\end{array}$ & Leaves & Ethanol extract & $\begin{array}{l}\text { The extract normalized liver functions and hepatic oxidative stress in } \mathrm{CCl}_{4} \\
\text { treated rats. The endogenous antioxidant defense was restored and lipid } \\
\text { peroxidation in the liver was reversed over } 7 \text { days' post-treatment with the } \\
\text { extract, similar to the effects shown by Legalon (Kalegari et al., 2014b). }\end{array}$ \\
\hline & Antinociceptive activity & Leaves & Hot water infusion & $\begin{array}{l}\text { Treatment of aqueous extract on mice resulted in the significant } \\
\text { antinociceptive effect on different pain models without affecting the motor } \\
\text { activity and corporal temperature of the mice, and the extract did not } \\
\text { depend on the opioid system (Kalegari et al., 2014a). }\end{array}$ \\
\hline & Acute toxicity & Leaves & Ethanol extract & $\begin{array}{l}\text { Ethanolic leaves extract of } R \text {. induta and its fractions showed no potential } \\
\text { toxicity in brine shrimp assay and hemolytic test (Oliveira et al., 2012). }\end{array}$ \\
\hline & Antibacterial activity & Leaves & $\begin{array}{l}\text { Ethyl acetate and } \\
\text { chloroform fractions of } \\
\text { ethanol extract }\end{array}$ & $\begin{array}{l}\text { Chloroform and ethyl acetate fractions of chloroform extract showed } \\
\text { inhibition against } S \text {. epidermidis and } S \text {. aureas (Kalegari et al., 2012). }\end{array}$ \\
\hline & $\begin{array}{l}\text { DPPH radical } \\
\text { scavenging activity }\end{array}$ & Leaves & $\begin{array}{l}\text { Ethyl acetate and } \\
\text { chloroform fractions of } \\
\text { ethanol extract }\end{array}$ & $\begin{array}{l}\text { The chloroform and ethyl acetate fractions of ethanol leaves extract of } R \text {. } \\
\text { induta showed significant DPPH radical scavenging activity with the } \mathrm{IC}_{50} \\
\text { values of } 5.3 \text { and } 3.2 \mu \mathrm{g} / \mathrm{ml} \text {, respectively (Kalegari et al., 2012). }\end{array}$ \\
\hline & $\begin{array}{l}\text { Phosphomolybdenum } \\
\text { complex method }\end{array}$ & Leaves & $\begin{array}{l}\text { Ethyl acetate and } \\
\text { chloroform fractions of } \\
\text { ethanol extract }\end{array}$ & $\begin{array}{l}\text { Hexane, chloroform, and ethyl acetate fractions of ethanolic leaves extract } \\
\text { of } R \text {. induta showed more than } 100 \% \text { activity in relation to rutin and } \\
\text { vitamin C (Kalegari et al., 2012). }\end{array}$ \\
\hline R. cuspidata & Hypoglycemic activity & Stems & Ethanol and water extracts & $\begin{array}{l}\text { Oral administration of hydroalcoholic stems extract of } R \text {. cuspidata at } 200 \\
\mathrm{mg} / \mathrm{kg} \text { significantly reduced the glucose level in streptozotocin-induced } \\
\text { diabetic rats comparable to glibenclamide (Laikowski et al., 2017). }\end{array}$ \\
\hline R. doniana & Larvicidal activity & $\begin{array}{l}\text { Stems } \\
\text { Leaves }\end{array}$ & Hexane extract & $\begin{array}{l}\text { The chloroform leaves extract and hexane stems extract of } R \text {. doniana } \\
\text { caused } 88.9 \% \text { mortality rate of the Aedes aegyptii larvae at the } \\
\text { concentration of } 250 \mu \mathrm{g} / \mathrm{ml} \text { (Oliveira et al., 2010). }\end{array}$ \\
\hline
\end{tabular}

significant after 90 and 120 minutes administration of the extract. Administration of 100,200 , and $400 \mathrm{mg} / \mathrm{kg}$ of methanol extract resulted in a significant reduction of hyperglycemia at days 4 , 8 , and 12 in a dose-dependent manner. Oral administration of methanol roots extract of $R$. minor at all doses significantly reduced glucose level in the diabetic rats (Chaudhary et al., 2012).

In another study, hypoglycemic activity was observed over 120 minutes in streptozotocin-induced diabetic rats treated with ethanolic and aqueous roots extract of $R$. minor at $400 \mathrm{mg} / \mathrm{kg}$ as compared to diabetic control rats. After 15 days, treatment with ethanolic and aqueous extracts reduced glycemia significantly at $43.1 \%$ and $34.8 \%$, respectively. The diabetic rats treated with ethanol extracts showed higher insulin secretion at $19.7 \mu \mathrm{U} / \mathrm{ml}$ as compared to those treated with water extract, which showed insulin secretion at $17 \mu \mathrm{U} / \mathrm{ml}$. The insulin secretion of diabetic control rats and glibenclamide treated rats $(10 \mathrm{mg} / \mathrm{kg})$ were less than 5 and $22 \mu \mathrm{U} / \mathrm{ml}$, respectively. Both extracts reversed the elevated lipid parameters and normalized them significantly to near normal values (Kulkarni et al., 2014).

\section{Rourea cuspidata}

Oral administration of hydroalcoholic stems extract of $R$. cuspidata at $200 \mathrm{mg} / \mathrm{kg}$ significantly reduced the glucose level in streptozotocin-induced diabetic rats comparable to glibenclamide. Hydroalcoholic extract contains flavonoids as major compounds. The extract showed a significant hepatoprotective effect on the rat's liver as shown by reduction of AST level from 253 to $49 \mathrm{U} / 1$ (Laikowski et al., 2017).

\section{Antibacterial activity}

The chloroform and ethyl acetate fractions of ethanol leaves extract of $R$. induta showed potential antibacterial activity against Staphylococcus aureas and S. epidermidis at $1,000 \mu \mathrm{g} / \mathrm{ml}$. Chloroform fractions showed inhibition against $S$. epidermidis and $S$. aureas with average inhibition halos of 12.3 and $7.6 \mathrm{~mm}$, respectively. Ethyl acetate fraction showed antibacterial activity against $S$. epidermidis and $S$. aureas with average inhibition halos of 15.0 and $7.6 \mathrm{~mm}$, respectively. Antibacterial activity of the ethanol extract could be due to the presence of hyperin $\mathbf{6}$, 
which showed antibacterial activity against $S$. epidermis at 1,000 and $500 \mu \mathrm{g} / \mathrm{ml}$ with average inhibition halos of 9.3 and $7.0 \mathrm{~mm}$, respectively (Kalegari et al., 2012).

\section{Hepatoprotective activity}

Administration of $500 \mathrm{mg} / \mathrm{kg}$ of ethanolic leaves extract of $R$. induta caused a significant reduction in AST and ALT activities and TB level in the $\mathrm{CCl}_{4}$ treated group comparable to Legalon. The weight of the liver of the treated group was also smaller as compared to the non-treated control group. Treatment with the extract also normalized the hepatic oxidative stress markers CAT, SOD, GPx, and GSH as compared to the nontreated control group, although Legalon showed a stronger effect. The endogenous antioxidant defense was restored and lipid peroxidation in the liver was reversed over 7 days post-treatment with the extract, similar to the effects shown by Legalon. The hepaprotective activity could be due to the presence of flavonoids 2, 3, and 6 (Kalegari et al., 2014b).

\section{Antinociceptive activity}

Treatment of aqueous leaves extract of $R$. induta on mice showed a significant antinociceptive effect on different pain models without affecting the motor activity and corporal temperature of the mice, and the extract did not depend on the opioid system. The aqueous extract inhibited the neurogenic (0-5 minutes) and inflammatory (15-30 minutes) phases of formalin-induced licking at 30,100, and $100 \mathrm{mg} / \mathrm{kg}$. The marker compound, hyperin $\mathbf{6}$, showed comparable result at $100 \mathrm{mg} / \mathrm{kg}$ at the neurogenic phase of the test. The mice in the extract treated group showed a significant reduction $(60 \%-65 \%)$ of the mechanical sensitivity on the ipsilateral paw when induced with intraplantar injection of Complete Freund's Adjuvant. The treatment of the extract reduced the level of IL- $1 \beta$ and TNF- $\alpha$ in the skin of the hind paw by $22 \%$ and $50 \%$, respectively, as compared to the non-treated control group. The treated group showed a significant reduction in biting behavior caused by TNF- $\alpha(0.1 \mathrm{pg} / \mathrm{site}$ i.t. $)$ but no effect was observed on IL-1 $\beta$-induced biting response. It was concluded that the antinociceptive effect of the aqueous leaves extract of $R$. induta is due to decrease synthesis or release of pro-inflammatory cytokines, such as TNF- $\alpha$ and IL- $1 \beta$ (Kalegari et al., 2014a).

\section{Antiplasmodial activity}

Rourinoside 38, rouremin 28, and 1-(26-hydroxyhexacosanoyl)-glycerol 26 isolated from $R$. minor showed antiplasmodial activity in vitro against chloroquine sensitive (D6) and chloroquine resistant (W6) Plasmodium falciparum with the $\mathrm{IC}_{50}$ values of $3.7 / 2.1 \mu \mathrm{M}, 5.1 / 4.5 \mu \mathrm{M}$, and 9.5/12.7 $\mu \mathrm{M}$, respectively (He et al., 2006).

\section{Larvicidal activity}

The hexane stems extract of $R$. doniana showed potential antilarvicidal activity with the $\mathrm{LD}_{50}$ value of $12.1 \mu \mathrm{g} / \mathrm{ml}$. The chloroform leaves extract and hexane stems extract of $R$. doniana caused $88.9 \%$ mortality rate of the Aedes aegyptii larvae at the concentration of $250 \mu \mathrm{g} / \mathrm{ml}$ (Oliveira et al., 2010).

\section{Acute toxicity}

No acute toxicity was observed when rats were given 100,200 , and $400 \mathrm{mg} / \mathrm{kg}$ of methanolic roots extract of $R$. minor (Chaudhary et al., 2012). In other study on ethanolic and aqueous roots extracts of $R$. minor, the rats showed good tolerance up to $3 \mathrm{~g} / \mathrm{kg}$ and no lethality was observed (Kulkarni et al., 2014). Ethanolic leaves extract of $R$. induta and its fractions showed no potential toxicity in brine shrimp assay and hemolytic test (Oliveira et al., 2012).

\section{Antioxidant activity}

DPPH radical scavenging activity

The chloroform and ethyl acetate fractions of ethanol leaves extract of $R$. induta showed significant DPPH radical scavenging activity with the $\mathrm{IC}_{50}$ values of 5.3 and $3.2 \mu \mathrm{g} / \mathrm{ml}$, respectively (Kalegari et al., 2012).

\section{Phosphomolybdenum complex method}

Hexane, chloroform, and ethyl acetate fractions of ethanolic leaves extract of $R$. induta showed more than $100 \%$ activity in relation to rutin and vitamin C. Hyperin 6 also demonstrated antioxidant activity more than $127.8 \%$ in relation to rutin but only more than $42.3 \%$ in relation to vitamin C (Kalegari et al., 2012).

\section{CONCLUSION}

Rourea sp. is widely used in traditional medicine for various health complaints. Scientific investigation on the plants yielded secondary metabolites of different classes. Several plants of Rourea sp. showed potential bioactivity, especially hypoglycemic and antinociceptive activities.

\section{ACKNOWLEDGMENTS}

The authors would like to express appreciation to Attaur-Rahman Institute for Natural Product Discovery, Universiti Teknologi MARA, for the facilities provided.

\section{CONFLICT OF INTEREST}

The authors declare no conflict of interest.

\section{FINANCIAL SUPPORT AND SPONSORSHIP}

The authors would like to thank Universiti Teknologi MARA for financial support through Bestari Perdana Grant (600IRMI/PERDANA 5/3 BESTARI (093/2018)).

\section{REFERENCES}

Alsarhan A, Sultana N, Kadir MRA, Aburjai T. Ethnopharmacological survey of medicinal plants in malaysia, the Kangkar Pulai region. Int J Pharmacol, 2012; 8:679-86.

Bargali S, Shrivastava SK, Dixit VK, Bargali K. Some less known ethno botanical plants of Jagdalpur district of Chhattisgarh state Botanica, 2003; 53:192-7.

Bero J, Ganfon H, Jonville M-C, Frédérich M, Gbaguidi F, DeMol P, Moudachirou M, Quetin-Leclercq J. In vitro antiplasmodial activity of plants used in Benin in traditional medicine to treat malaria. J Ethnopharmacol, 2009; 122:439-44.

Chaudhary A, Bhandari A, Pandurangan A. Anti-hyperglycemic potential of Rourea minor roots in streptozotocin (STZ) induced diabetic rats. Int J Pharm Res, 2012; 4:59-62. 
Forero E. Neotropical connaraceae. In: Milliken W, Klitgård B, Baracat A. (eds.). Neotropikey - Interactive key and information resources for flowering plants of the Neotropics. 2009. Available via http://www.kew. org/science/tropamerica/neotropikey/families/Connaraceae.htm (Accessed 20 Aug 2018).

Grosvenor PW, Gothard PK, McWilliam NC, Supriono A, Gray DO. Medicinal plants from Riau Province, Sumatra, Indonesia. Part 1: uses. J Ethnopharmacol, 1995; 45:75-95.

He Z-D, Ma C-Y, Tan GT, Sydara K, Tamez P, Southavong B, Bouamanivong S, Soejarto DD, Pezzuto JM, Fong HH, Zhang HJ. Rourinoside and rouremin, antimalarial constituents from Rourea minor. Phytochemistry, 2006; 67:1378-84.

Jamal JA, Ghafar ZA, Husain K. Medicinal plants used for postnatal care in Malay traditional medicine in the Peninsular Malaysia. Pharmacogn J, 2011; 3:15-24.

Jeannoda VLR, Rakoto-Ranoromalala DAD, Valisolalao J, Creppy EE, Dirheimer G. Natural occurrence of methionine sulfoximine in the Connaraceae family. J Ethnopharmacol, 1985; 14:11-7.

Kalegari M, Cerutti ML, Macedo-Júnior SJ, Bobinski F, Miguel MD, Eparvier V, Santos AR, Stien D, Miguel OG. Chemical composition and antinociceptive effect of aqueous extract from Rourea induta Planch. leaves in acute and chronic pain models. J Ethnopharmacol, 2014a; 153:801-9.

Kalegari M, Gemin CAB, Araújo-Silva G, Brito NJNd, López JA, Oliveira Tozetto SD, das Graças Almeida M, Miguel MD, Stien D, Miguel OG. Chemical composition, antioxidant activity and hepatoprotective potential of Rourea induta Planch. (Connaraceae) against $\mathrm{CCl}_{4}$-induced liver injury in female rats. Nutrition, 2014b; 30:713-8.

Kalegari M, Miguel MD, Dias JDFG, Lordello ALL, Lima CPD, Miyazaki CMS, Zanin SM, Verdam MC, Miguel OG. Phytochemical constituents and preliminary toxicity evaluation of leaves from Rourea induta Planch. (Connaraceae). Brazil J Pharm Sci, 2011; 47:635-42.

Kalegari M, Miguel MD, Philippsen AF, de Fátima Gaspari Dias J, Zanin SMW, de Lima CP, Miguel OG. Antibacterial, allelopathic and antioxidant activity of extracts and compounds from Rourea induta Planch. (Connaraceae). J Appl Pharm Sci, 2012; 2:061-6.

Kantati YT, Kodjo KM, Dogbeavou KS, Vaudry D, Leprince J, Gbeassor M. Ethnopharmacological survey of plant species used in folk medicine against central nervous system disorders in Togo. J Ethnopharmacol, 2016; 181:214-20.

Kulkarni P, Patel V, Shukla ST, Patel A, Kulkarni V. Antidiabetic potential of Rourea minor (Gaertn.) root in streptozotocin-induced diabetic rats. Oriental Pharm Exp Med, 2014; 14:69-76.
Laikowski MM, dos Santos PR, Souza DM, Minetto L, Girondi N, Pires C, Alano G, Roesch-Ely M, Tasso L, Moura S. Rourea cuspidata: chemical composition and hypoglycemic activity. Asian Pac J Trop Biomed, $2017 ; 7: 712-8$.

Oliveira PV, Ferreira JC, Moura FS, Lima GS, de Oliveira FM, Oliveira PES, Conserva LM, Giulietti AM, Lemos RP. Larvicidal activity of 94 extracts from ten plant species of northeastern of Brazil against Aedes aegypti L. (Diptera: Culicidae). Parasitol Res, 2010; 107:403-7.

Oliveira PVD, Lemos RPL, Conserva LM. Chemical constituents of Rourea doniana. Rev Brasil Farmacogn, 2012; 22:451-4.

Ong HC, Ahmad N, Milow P. Traditional medicinal plants used by the Temuan villagers in Kampung Tering, Negeri Sembilan, Malaysia. Studies Ethno Med, 2011a; 5:169-73.

Ong CH, Chua S, Milow P. Ethno-medicinal plants used by the Temuan villagers in Kampung Jeram Kedah, Negeri Sembilan, Malaysia. Studies Ethno Med, 2011b; 5:95-100.

Ramiah N, Prasad NBR, Abraham K. Rapanone and leucopelargonidin from the roots of Rourea santaloides. J Inst Chem (India), 1976; 48:196-7.

Sabran SF, Mohamed M, Abu Bakar MF. Ethnomedical knowledge of plants used for the treatment of tuberculosis in Johor, Malaysia. Evid Based Complement Altern Med, 2016; 1-12.

Sanz-Biset J, Cañigueral S. Plant use in the medicinal practices known as "strict diets" in Chazuta valley (Peruvian Amazon). J Ethnopharmacol, 2011; 137:271-88.

The Plant List. Version 1.1. Published on the Internet. 2013 Available via http://www.theplantlist.org/ (Accessed 28 December 2018).

Zhang KM, Jiang JQ, Kong L. Chemical constituents from Rourea microphylla. Chinese J Nat Med, 2008; 6:345-7.

How to cite this article:

Osman CP, Zahari Z, Adenan MI, Zohdi RM. A review on traditional uses, phytochemistry, and pharmacology of the genus Rourea. J Appl Pharm Sci, 2019; 9(09):125-131. 